\title{
Agriculture in a Developmental State: Finding the Nexus for Development(al) Agricultural Economists ${ }^{1}$
}

\author{
Moraka Nakedi Makhura \\ Department of Agricultural Economics, Extension and Rural Development \\ University of Pretoria \\ Moraka.makhura@up.ac.za
}

2015 FR Tomlinson Memorial Lecture, delivered at Bolivia Lodge, Polokwane on 1 December $2015^{2}$

\section{Introduction}

First of all, I feel very honoured and humbled to present this prestigious FR Tomlinson Memorial Lecture, particularly in my home province of Limpopo where I cut my teeth of service as an agricultural economist. It all started in the early days of my primary schooling where I observed extension officers assisting farmers to manage their micro-farm enterprises at our Eldorado village in Blouberg. It was a place well-endowed with underground water, good arable soil and sweet grazing land (though with less than normal rainfall). Years later, I had the opportunity to serve the Agricultural Economics profession through the Agricultural Economics Association of South Africa (AEASA) Management Committee at different (if not all) portfolios ${ }^{3}$. Then, I persuaded the association to open up to agricultural economists from different spaces, particularly from the provinces. This year marks 25 years since I started practising as an agricultural economist, and having attended

1 The paper benefited a great deal from inputs and guidance of Dr. Petronella Chaminuka of the ARC.

2 Thanking the Limpopo Province Agricultural Economists Working Group and AEASA Management Committee for the honour to present the FR Tomlinson Memorial Lecture.

3 As "provincial coordinator", additional member, Secretary/Treasurer, Vice-President, President, Past President, BD Nomvete Bursary Trustee, Chair of Editorial Committee of AEAS Book, etc. 
the first AEASA event - the FR Tomlinson Lecture that was presented by Prof. Jan Groenewald in 1990 - which inspired my professional journey. This remarkable honour is also happening in a year when I become a half-Centenarian!

This lecture is dedicated to my mother, Sethodi Maggie Makhura (maiden Sebola), who was laid to rest about three weeks ago. She is my role model farmer! By the time of her passing, she had planted a backyard full of butternuts targeting Christmas time. On the morning of her passing, she irrigated the plants before she took her rest. I still have statements of her past records from the Joburg Fresh Market where she used to send her pepper, garlic and butternuts! She inspired me to be a passionate agricultural economist. With her, we would work to sell some of my livestock so that we rejuvenate the herd. Interestingly, she was a different farmer from my dad, Nakedi Abraham Makhura, who, after I completed my research on commercialisation, totally declined my advice for him to sell some of the livestock. He emphatically dismissed me with a counter advice: "buy your own cattle and sell them". Indeed, now that I have cattle, I realise how hard it is to part with one's precious assets. The only easiest time to sell is during periods of drought when cattle are dying and sold at plummeting prices! The farming aspirations and experiences run through all my extended family, and most importantly, represent experiences of many emerging farmers out there.

Today, I ask myself, what would FR Tomlinson do or say for these farmers? FR Tomlinson was the co-founding member President of AEASA in 1961. His major developmental work and contribution that I can identify with emanated from his role in the Tomlinson Commission that looked into the feasibility of homelands' economies. He recommended that more land should be made available to the homelands in order to expand the available area for farming. That is, farmers were to be settled on viable farms. The question is, what do we learn from him?

This lecture traces efforts of locating agriculture in the economy. It builds on several Tomlinson commemorative lectures that addressed the question of development and the position of agriculture and agricultural economists in the economy (Fraser, 2010; Potgieter, 2014; Van Zyl, 2008; Vink, 2001). It is very much in line with Potgieter (2014), who even advised me to have fun on the eve of this lecture. The lecture acknowledges the contribution of the Agricultural Economics profession to the agricultural development debate, but argues that we may have missed opportunities to better align ourselves with the contemporary developmental agenda at some critical points. I suggest some different thinking in terms of South Africa's approach to agricultural development and some tested ways of positioning ourselves more precisely at the development nexus. 


\section{Why Agriculture in the Developmental State?}

The issue of the development state is meant to stimulate debate within the Agricultural Economics profession around the role of agriculture in the economy. For some time, the issue of development has been off the list of agricultural economics discussions, yet the priorities of government have also stipulated new expectations from the agricultural sector. The South African agricultural sector has been responding to these expectations within the government departments, but formal engagements about the implications for agriculture in the economy have been minimal.

Other sectors have engaged and illustrated their perspectives in the notion of the Developmental State (Marwala, 2006; Edigheji, 2010; Maserumule, 2010). With agriculture being the source of food, it has high potential to drive the Developmental State objectives.

It can be argued that South Africa has been on a Developmental State mode since 1994. Hence, the attempt has been to trace the performance of agriculture since that time.

\section{About the Developmental State}

Since 1994, South Africa adopted a formal developmental path aimed at building a society with empowered citizens and equal opportunities. Accordingly, this would eliminate poverty and inequality. According to Marwala (2006), reorientation towards a Developmental State is one mechanism to channel productive forces towards these goals.

Johnson (1982), who is regarded as the first person to define the notion, defined the Developmental State as one focused on economic development and takes necessary policy measures to accomplish that objective. A Developmental State is a state where government is intimately involved in macro- and micro-economic planning in order to grow the economy (Onis in Marwala, 2006) or simply a phenomenon of state-led macro-economic planning. According to Education and Training Unit for Democracy and Development or ETU (2015), a Developmental State plays an active role in guiding economic development and in using the resources of the country to meet the needs of the people. A Developmental State tries to balance economic growth and social development. It uses state resources and state influence to attack poverty and to expand economic opportunities.

A Developmental State must be able to direct and support economic development shaping the structure and output of the economy through a strong public service, an investor friendly environment, thriving small business development, effective state-owned enterprises and strategic investment initiatives. The state has to keep the economy competitive and close to the leading edge in the global development. 
The Developmental State usually has the following four major attributes:

- The government keeps a closer focus on the macro plans. In this regard, the question would be the agri-macro plans required to support developmental objectives of the state.

- The state endeavours to balance social and economic imperatives. The further question is then how can agriculture contribute or play a role in supporting the state to achieve both social and economic objectives?

- The state makes a major intervention in industrialisation. Japan is considered a "Developmental State" due to its active involvement in industrialisation. This is unlike the US, which is dubbed more of a "Regulatory State" since it relies on institutions to implement the programmes. South Africa is also beginning to promote industrialisation through the Industrial Policy Action Plan (IPAP) and the Black Industrialist Programme. The question is what contribution can agriculture make in the process? To determine that, different stakeholders in agriculture need to assess and interrogate the potential that agriculture has in industrialisation.

- The final attribute is that government leads the implementation of developmental programmes.

Within the African context, Mkandawire (2001) asserts that Africa has had states that were developmental in both aspirations and economic performance. Botswana, for example, is regarded as a Developmental State (Johnson, 1982). Mkandawire draws lessons from Asian countries, where the state has played a central role in the development of the countries. Such lessons may pose replication difficulties due to a) state dependency, b) lack of focused ideology, c) the "softness" of the African state and its proneness to "capture" by special interest groups, d) lack of technical and analytical capacity, e) the changed international environment that does not permit protectionist industrial policies, and f) the poor record of past performances.

According to some developmental political scientists such as Maseti (2015), South Africa is nowhere closer to displaying the characteristics of a Developmental State as defined by Mkandawire. This infers that South Africa's claim to be a Developmental State could be more aspirational rhetoric. However, for the purpose of this lecture, developmental efforts in South Africa include a set of efforts to improve and enhance the overall welfare of the citizens. This was based on several national economic frameworks such as the Reconstruction and Development Programme (RDP); Growth, Employment and Redistribution (GEAR); Accelerated Shared Growth Initiative of South Africa (ASGISA); as well as the Freedom Charter and the Constitution, that provided for development and social justice (Makhura, 2008b). As such, the developmental aspiration of South Africa dates far back and the 
contemporary developmental efforts could be traced back to the 1990s ever since the new South African democratic dispensation dawned.

When the current government took office, it re-proclaimed the need to build a Developmental State. The Developmental State requires government's active involvement in the macro- and micro-planning of the economy. Hence, the establishment of the National Planning Commission that developed the National Development Plan (NDP). Maserumule (2010) referred to the effort as consolidation of a developmental agenda.

For South Africa, the commitment to a Developmental State is reflected in the efforts to mobilise the resources of society and direct them towards the realisation of common goals. These goals have been stated and restated in different ways and contexts. By 2010, the priorities were organised into 12 outcomes to give effect to priorities in education, security and corruption, health, human settlement, as well as rural development and land reform (Land Bank Policy Insight, 2010). The rural outcomes were about expanding commercial farming and agri-processing to create jobs, and increasing the number of small-scale farmers and their market share. As such, the role of agriculture is eminent in the effort. Basically, agriculture tends to respond accordingly to the direction set by the state, thus making it a pertinent instrument to contribute to Developmental State purposes (Johnston, 1992).

Perhaps a more analytical perspective would be to describe and compare the main objectives described in the Reconstruction and Development Programme (RDP) in 1994 and the National Development Plan (NDP), which was formulated some 20 years later on. The RDP was meant to reconstruct the economic structure to enable participation. The NDP, on the other hand, assumes a more sectoral approach, and could be regarded as the extension of RDP since it does not differ with it significantly in the underlying objectives. Both development frameworks also suggest different instruments and targets. In response to such development frameworks, agriculture developed sectoral positions using the same principles. For example, following the RDP, the Broadening Access to Agriculture Thrust (BATAT) was conceived and policy to distribute $30 \%$ of agricultural land was implemented. Currently, the Agricultural Policy Action Plan (APAP) is intended to align the agricultural sector to the NDP. Similarly, agricultural responses have been made in line with national broader level policy positions. Table 1 illustrates the level of responsiveness of agriculture to national macro policy directions. 
Table 1: Developmental State priorities and agricultural sector response

\begin{tabular}{|l|l|}
\hline \multirow{2}{*}{ National Policy Instruments } & $\begin{array}{l}\text { Agricultural Sector Policy Instrument } \\
\text { Response }\end{array}$ \\
\hline $\begin{array}{l}\text { Reconstruction and Development } \\
\text { Programme (RDP) ( 1992) }\end{array}$ & $\begin{array}{l}\text { Broadening Access to Agriculture Thrust } \\
\text { (BATAT) (1994) }\end{array}$ \\
\hline $\begin{array}{l}\text { Provisional Constitution (1994); } \\
\text { Constitution of the Republic of South } \\
\text { Africa (1996) }\end{array}$ & White Paper on Agriculture (1995) \\
\cline { 2 - 2 } $\begin{array}{l}\text { Growth, Employment and } \\
\text { Redistribution (GEAR) - 1999 }\end{array}$ & Policy on Land Reform (1995) \\
\hline $\begin{array}{l}\text { Black Economic Empowerment (BEE) } \\
\text { Broad Based Black Economic } \\
\text { Empowerment (BBBEE) }\end{array}$ & $\begin{array}{l}\text { Agricultural Sector Strategy (2001) } \\
\text { Strategy (ISRDS) - 2001 }\end{array}$ \\
\hline $\begin{array}{l}\text { Accelerated \& Shared Growth Initiative } \\
\text { of South Africa (ASGISA) }\end{array}$ & Land \& Agrarian Reform Programme (LARP) \\
\hline New Growth Path & $\begin{array}{l}\text { Comprehensive Rural Development } \\
\text { Programme }\end{array}$ \\
\hline Industrial Policy Action Plan (IPAP) & Integrated Growth \& Development Plan \\
\hline $\begin{array}{l}\text { National Development Plan (NDP) - } \\
\text { 2011 }\end{array}$ & Agricultural Policy Action Plan (APAP) \\
\cline { 2 - 2 } & Revised Land Reform Policies \\
\hline
\end{tabular}

\section{Role of Agricultre in the South African Developmental Economy}

Perhaps to provide further impetus to the focal theme of this lecture, it is worthwhile to consider the issue of agriculture within the broader economic development. This will be done by looking at the theories of agricultural transformation (development), the contribution of agriculture in the South African economy, as well as the evolution of the sector over time. The analysis of agriculture's position is done in line with the thread of national development. The prime objective of development is to create an increase in general living standards for all members of the population (Makhura,1990). Development, as indicated by Coetzee (1987), "is for the people".

\subsection{Understanding the Role of Agriculture in the economy}

In his chapter focusing on role of agriculture in economic transformation, Timmer (1990) identifies four stages that position the economic role of agriculture. The first phase is Getting Agriculture Moving (as described by Mosher in the same text), which 
involves institutional change, technology development, provision of incentives and development of infrastructure. At this stage, agriculture would be more subsistent, and the economy still not well developed. South African agriculture has largely passed this stage. The second phase is about Making Agriculture Contribute to the Economy (as described by Johnston-Mellor). At this phase, agriculture is made to link with other industries, with focal efforts being to create a healthy agricultural sector that performs, and then mobilising resources. While this stage is in line with the subject, South African agriculture has also passed this stage. The third phase involves Integrating Agriculture into the Macro-Economy (Schultz-Ruttan), by responding to macro-economic instruments, making agriculture efficient, with resources moving out of agriculture to other sectors. At this stage there will be high rural/urban disparities as resources move to more efficient sectors and areas. The fourth stage is when Agriculture is in the Industrial Economies (as proposed by DG Johnson). At this stage, there is a small share of agriculture in the economy, high unemployment and need for labour in agriculture.

South African agriculture tends to resonate with most elements of the last two stages. However, when dissected further, there are still some sectors of agriculture that must still get moving and made to contribute to the overall economy. For example, the previously disadvantaged sector, the emerging farmers, agriculture in the former homelands, and the new beneficiaries of land reform still require institutional interventions, improved technology, incentives and infrastructure to get moving. The key questions that could be asked is which stage is most desirable for South Africa's real farmer? My submission is that the stages do not fit the multifaceted South African situation.

As such, the best view for South Africa is to consider another economic trajectory. The most pertinent trajectory is the Developmental State or Developmental Economy. Thus, we could define the fifth stage as Agriculture in a Developmental State or Economy. South Africa adopted this type of economy to address its emergence from apartheid to freedom. This is probably a typical type of state to be adopted by countries emerging from economic disparities and political tensions. Most African countries should have gone through this stage. However, for agriculture, this means reconstruction and unification of the sector. The question is what has been the contribution of agriculture in South Africa? 
Table 2: Stages of Agricultural Transformation

\begin{tabular}{|l|l|}
\hline STAGES & ATTRIBUTES \\
\hline Getting Agriculture Moving & $\begin{array}{l}\text { Moving through institutional change, technology, } \\
\text { incentives and infrastructure (Mosher) }\end{array}$ \\
\hline $\begin{array}{l}\text { Making Agriculture } \\
\text { contribute to the Economy }\end{array}$ & $\begin{array}{l}\text { Linkages with industry, create healthy agricultural sector } \\
\text { and mobilise resources (Johnston-Mellor) }\end{array}$ \\
\hline $\begin{array}{l}\text { Integrating Agriculture into } \\
\text { the macro-economy }\end{array}$ & $\begin{array}{l}\text { Responds to macro-economic instruments, efficiency, } \\
\text { resources out, and rural/urban disparities (Schultz-Ruttan) }\end{array}$ \\
\hline $\begin{array}{l}\text { Agriculture in Industrial } \\
\text { Economies }\end{array}$ & $\begin{array}{l}\text { Small share of agriculture, unemployment and need for } \\
\text { labour in agriculture, with disparities (DG Johnson) }\end{array}$ \\
\hline $\begin{array}{l}\text { Agriculture in a } \\
\text { Developmental State }\end{array}$ & $\begin{array}{l}\text { Agriculture contributing to food security, providing strong } \\
\text { forward and backward linkages, creating e } \\
\text { employment, instrument of transformation }\end{array}$ \\
\hline
\end{tabular}

Adapted from Timmer (1990:51)

As indicated earlier, the Developmental State involves an active leading role by the state in national macro plans and outputs. From the input side (national budgeting), there has been concerns that agriculture is not given the necessary latitude to be the instrument of transformation.

\subsection{Contribution of Agriculture in the South African Economy}

The measure of performance of South African agriculture can be considered from three perspectives. These are the conventional perspective, extended view and evolutionary market perspective.

\subsubsection{The conventional perspective}

Table 3 presents the conventional perspective of the contribution of agriculture in the economy. The agricultural share of the GDP is about $2.4 \%$ of the GDP, down from about $12 \%$ about 60 years ago. This, in part, reflects that the economy is more developed with the secondary and tertiary sector contributing more to the GDP. The number of workers employed in agriculture is just more than half of the level 60 years ago, with the percentage share just around $5 \%$ of the total workforce. Does this mean agriculture is losing its economic significance or not enough is being done to make agriculture responsive to economic or policy drivers?

One answer would be that South Africa is becoming more industrialised. Nonetheless, agriculture contributes to foreign exchange as South Africa has been a net exporter of food over the years and it also contributes to government revenue through taxes. 
Table 3: Contribution of Agriculture in the Economy: Conventional Perspective

\begin{tabular}{|l|r|r|r|r|}
\hline & Around 1954 & $\mathbf{1 9 9 4}$ & $\mathbf{2 0 0 4}$ & $\mathbf{2 0 1 4}$ \\
\hline GDP (\% share) & $12-18$ & 4.6 & 3.1 & 2.4 \\
\hline Employed in Agriculture & +1300000 & 921700 & 767000 & 686000 \\
\hline Share of Employment (\%) & $20-30$ & 19 & 6 & 5 \\
\hline Foreign Exchange (x-m) (R) & & 3160,9 & 6241,2 & 20262,7 \\
\hline Import/Export Dependence (\%) & & $61 \%$ & $73 \%$ & $75 \%$ \\
\hline Net Farm Income (R) & & 6768.1 & 16252.6 & 65953.4 \\
\hline
\end{tabular}

Source: Adapted from Department of agriculture, Land Bank Annual Reports \& Stats SA

\subsubsection{Extended perspective of the contribution}

A cursory glance at the table above might be misleading as the value of agriculture in South Africa has been increasing and its significance has been growing. As asserted in his FR Tomlinson address after spending a decade outside Agricultural Economics, Van Zyl (2008: 395) stated that "agriculture's role in and contribution towards the South African economy still exceeds its contribution to the GDP, particularly given our developmental state and linkages of agriculture with secondary and tertiary sectors". The first extended measure is the simple value of agricultural production, which stands at about R200 billion in nominal terms, an almost 100\% increase in five years. Agriculture is also the most connected sector through forward and backward linkages. It creates demand for agricultural inputs and services (backward linkages) and enables manufacturing and processing of foodstuff (forward linkages). Another area of importance is the total trade (exports plus imports) that helps the country to achieve its strategic relations. The most critical contribution in the extended measure is food security. The stable food conditions in the country enable other economic activities to progress. In simple terms, everyone must have eaten before doing other jobs. That means that everyone inevitably depends on agriculture every day before, during and after any activity. Now, you tell me that agriculture or farming is not important!

However, the current state of food security depends on market stability and a range of macro-economic conditions. Frequently expressed concerns about food insecurity are not necessarily because agriculture has failed to produce, but rather because the national system is failing in terms of the right policies and incentives to stimulate distribution, access and affordability in the agricultural value chain, among other issues. This is unarguably a domain where Agricultural Economics has a big role to play in terms of policy analysis and advice. 
Table 4: Extended Contribution of Agriculture in the Economy

\begin{tabular}{|c|c|c|c|c|}
\hline & $\begin{array}{r}\text { Around } \\
1954\end{array}$ & 1994 & 2004 & 2014 \\
\hline Value of Agriculture (R'm) & 1000 & 29941.3 & 110000 & 208000 \\
\hline $\begin{array}{l}\text { Forward Linkages: Output } \\
\text { supply for manufacturing } \\
(\%)\end{array}$ & - & - & +68 & 70 \\
\hline $\begin{array}{l}\text { Backward Linkages: } \\
\text { Agric demand for } \\
\text { intermediate inputs } \\
\text { (R'million) }\end{array}$ & - & - & 62900 & 110400 \\
\hline $\begin{array}{l}\text { Foreign exchange: Agric } \\
\text { trade }(x+m) \text { (R'million) }\end{array}$ & - & 12950700 & -/+ R85 000 & $\begin{array}{r}-/+\mathrm{R} 142 \\
000\end{array}$ \\
\hline Food security state & $\begin{array}{r}\text { Food } \\
\text { production } \\
\text { stability: } \\
\text { intermittent } \\
\text { shortage }\end{array}$ & $\begin{array}{r}\text { Food } \\
\text { access } \\
\text { disparities }\end{array}$ & $\begin{array}{r}\text { Food self- } \\
\text { reliance: } \\
\text { (from income } \\
\text { to price } \\
\text { insecurity) }\end{array}$ & $\begin{array}{l}\text { Market } \\
\text { stability }\end{array}$ \\
\hline
\end{tabular}

Source: Adapted from Department of agriculture, Land Bank Annual Reports \& Stats SA

\subsection{Rising value of agriculture and institutional complexity}

The other way to comprehend the position and condition of agriculture is by looking at the evolution of complexity in input and output markets. As the agricultural institutions (markets) evolve, the critical role of agriculture changes. In the early years (before the 1950s) of food production stability, product markets were more favourable and inputs were cheaper and accessible. Farmers were only worried about producing. The next era (after the 1950s) saw a cost price squeeze when input prices were rising faster than output prices. Farmers were able to focus on production due to the support and incentives that sustained the agricultural contribution. Since deregulation of markets in the 1990s, output markets became more volatile, while input prices were increasing. Profit was made only on condition of more output market intelligence that guided decision-making. Since the 2000s, agriculture had to operate in the market economy where both output and input markets became volatile and cyclical. This requires forward-looking and strategic decision-making. The result is that farmers have to focus on profit margins, and that creates vulnerability to food availability. 


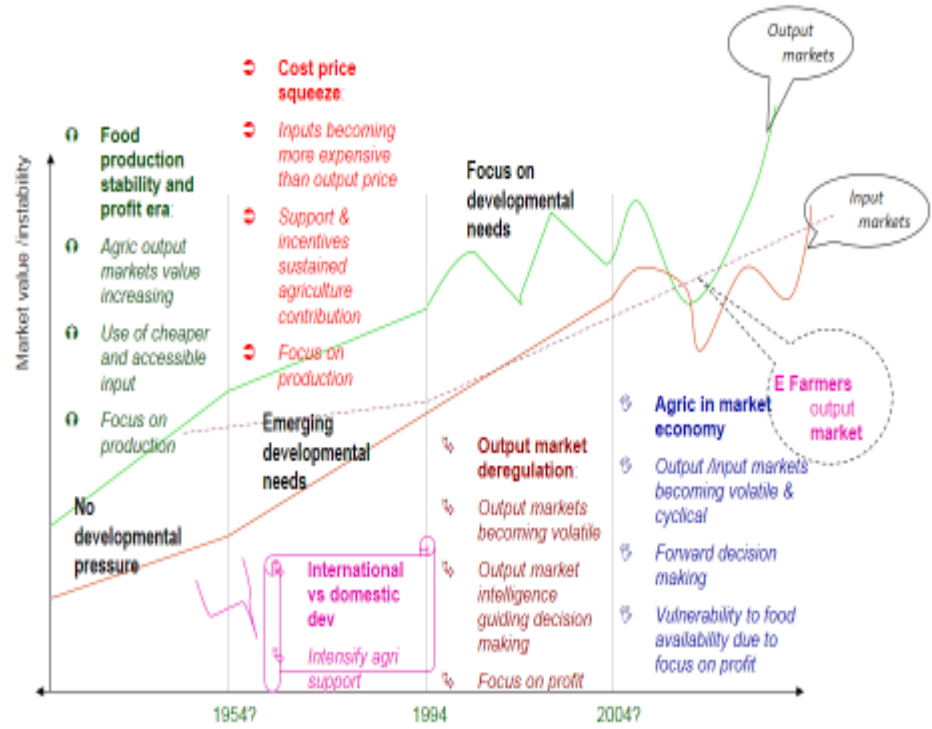

Figure 1: Evolution of Agriculture in South Africa: Market perspective

Source: Makhura (2008a)

In summary, within the Developmental State perspective, there is a need to guide agriculture to contribute the developmental dimensions of the economy. A critical issue to reflect on as the Agricultural Economics profession, is whether we have, by and large, acknowledged the deficiencies of the market system and advised appropriately on the policy and institutional options for fostering free market conditions, while taking cognisance of inherent market failure problems. Judging by the number of agricultural economists in organisations such as the Agricultural Research Council, the National Agricultural Marketing Council and the Land Bank, one could argue that indeed the Agricultural Economics profession has been visible to some extent in steering markets for a Developmental State. 


\section{Agricultural Economists and the Developmental Mission}

\subsection{The practice of agricultural economists: then and now}

\subsubsection{Focus of agricultural economists in development projects (pre-1994)}

Potgieter (2014) notes how in the period before 1994, the government promoted development projects owned by both the state and the private sector within communities. Most of these projects were in the homelands. Agricultural economists played a major role in preparing project proposals and conducting feasibility studies. Such assignments involved using project evaluation techniques (with different modules involving technical, economic, financial, social and environmental aspects of project analysis). The projected cash flows would then be used to test the viability of the project. Extensive work was done in that respect.

\subsubsection{Focus of Agricultural Economists in Farm business (Post 1994)}

With the provincialisation and prioritisation of introducing farm businesses in the development of agriculture in recent years, agricultural economists have been using business plans as tools for scoping farming projects. Through these, the feasibility and potential viability of a proposed or existing farm business, could be ascertained. My understanding (subject to correction) is that this applied to farmers who are likely to receive government support or intervention. While the effectiveness of the business plan approach still needs to be assessed formally, I have always wondered how many farmers a single Agricultural Economist could serve? In my earlier work in the Limpopo Province (in fact in the former Lebowa homeland), I could only manage to visit and work effectively with about five farmers in a week's round of visits. This excluded follow-up meetings to monitor that the farmer is addressing the issues discussed. The coverage was so thin that one needed to work with local extension officers who could follow through on some of the recommendations. We tested or tried the adoption of farm record management and enterprise budgeting. However, I could not be sure how much was appreciated by both the farmer and the extension officer. In trying to reach more interest groups, I even tried to run a column on Managing Small Farm Business in the Small Business News published by the University of Limpopo.

From a Development Economics perspective, it is about the scale of beneficiation, even beyond farm level. That is, how many beneficiaries could be covered by a proposed initiative? 


\subsubsection{Is there a need to scale up viability analysis?}

There are several objectives and targets that are micro-managed by the Developmental State, which agricultural economists cannot wish away unless they become part of the solution. One of those is the question of land reform and resettlement of farmers.

South Africa has been involved in a land reform process for the past 20 years. So far, communities and farmers have been settled, unsettled and resettled in different farms. The process is proceeding with or without agricultural economists. Somehow, agricultural economists have been coming into the process ex post to evaluate and critique post-settlement arrangements. The ex ante assessment of land reform projects has been left to the political, legal, historical and administrative processes. One wonders how much value could have been added if each land reform project was subjected to formal economic project evaluation, with feasibility and viability tests being undertaken. Most probably, this would have avoided the emerging challenges where land reform projects have become sources of conflict instead of sources of livelihood. We could have made them more viable and avoided failures that are sometimes shown in the public domain. However, it is worthwhile to recognise some great work done by agricultural economists in the land reform projects ex post. One fascinating innovative initiative I came across was on how to apply cooperative principles in the governance of land reform projects.

\subsection{AEASA's attitude to developmental priorities}

There are several dimensions from which to assess whether AEASA provides a good platform for agricultural economists to reflect on and support the Developmental State. These would entail discerning the extent to which the issue of development is carried in themes of annual conferences, keynote addresses such as the Simon Brand Memorial Address and the FR Tomlinson Memorial Lectures, Agrekon articles, conference paper titles and presidential addresses.

\subsubsection{AEASA conference themes}

In looking at the conference themes that AEASA hosted, some observations surface. Without being too stringent, out of about 50 conferences, one could associate about 11 of the themes as being developmental. The interesting observation is that in the early years of the AEASA, themes seemed to have been more pointed and linked to specific developmental or policy issues. However, in later and recent years, they became more generalised. The question is, what difference would it have made to have a theme focusing on the National Development Plan? The debates and shifts towards the Developmental State national development orientation happened in the midst of agricultural economists! While other professions interrogated it and positioned their sectors accordingly, the agricultural economics profession took the business as usual position. 
Table 5: AEASA Conference Themes related to development

\begin{tabular}{|l|l|}
\hline Themes & Period \\
\hline Planning of Agricultural Development & 1966 \\
\hline Rural development in South Africa & 1968 \\
\hline Economic development of agriculture in less developed areas & 1969 \\
\hline The Commission of Enquiry into agriculture: An evaluation & 1973 \\
\hline The computer as aid in agricultural development & 1982 \\
\hline The role of agricultural economist in the restructuring process & 1995 \\
\hline Agriculture's economic role in Southern Africa in the new millennium & 1998 \\
\hline Rural development and competitiveness & 2002 \\
\hline Agriculture in a democratic society,1994-2004 & 2004 \\
\hline From policy reform to implementation and delivery in South African agriculture & 2007 \\
\hline Rethinking agriculture and rural development in Southern Africa & 2008 \\
\hline
\end{tabular}

Source: AEASA 2011: Fifty Years of Achievement

\subsubsection{Simon Brand Memorial Lecture}

In terms of Simon Brand Memorial Lecture, about three out of the 23 focal themes could be classified as being developmental. Among them is Bruce Johnston from Stanford University who looked at "Agriculture and structural change: are there historical lessons for South Africa" in 1992. In 1994, Hans Binswanger from the World Bank addressed under the topic "Agriculture and rural development: painful lessons in 1994", and Jo Swinenn from the Katholieke Universiteit in Leuwen, Belgium, focused on "Agricultural transformation: lessons from experience in 2004".

The irony is that Simon Brand was a very strong developmentalist. He is the founding CEO of the Development Bank of Southern Africa (DBSA), which in many ways, has led the development agenda (Van Rooyen and Vink, 2015). One would have expected more development perspectives emerging from the lecture.

\subsubsection{FR Tomlinson Memorial Lecture}

Coming to my counterparts who presented the FR Tomlinson Lecture, the more pointed themes were in the early years of the lecture. In 1993, Nieuwoudt addressed on the topic "South African land reform: a policy evaluation". Most of the lectures touched on the issue of developmental questions and developmental economists in the content. For example, Potgieter (2014) addressed the versatility of agricultural economists that included a developmental dimension. Van Rooyen (2000) illustrated the sound Development Economics of the 1950s that made Tomlinson 
a Developmental Economist. Vink (2001) observed how much was done on small farmer research and in the main, illustrated the developmental interventions. Apart from the fact that the lectures were not themed and tagged with precisely the word "development", most of them picked up the issue in the discourse.

\subsubsection{Agrekon articles since the National Development Plan (NDP)}

The NDP has set South Africa's long-term developmental vision. It is worthy to acknowledge that a few agricultural economists played a role in the preparation of the NDP as Commissioners, provision of information for planning and policy perspectives. The question is to what extent has the broader agricultural economics profession embraced the NDP?

A quick survey of few samples randomly picked Agrekon journal volumes for the past four years (2013 to 2015) shows how agricultural economists reflected or reacted to the direction of the Developmental State. Initially the intention was to identify any reference to the NDP since its launch. The first round of the snap survey revealed that there was very little reference to the NDP even if though the plan made very specific recommendations about agriculture. From this, it can be inferred that agricultural economists do not appreciate national efforts to enhance development or the interventionist instruments deployed by the Developmental State. It could be that indeed we react, ex post, in mostly a criticising role. 
Table 6: Agrekon articles covering developmental themes

\begin{tabular}{|c|c|c|}
\hline Author & Reflected in Title & Reflected in the Text \\
\hline Mmbando et al (2015) & Small farmer participation & \\
\hline Dlamini et al (2014) & Land reform & \\
\hline Thorn and Conradie (2014) & Urban agriculture & Food security, poverty (p65) \\
\hline Jordan et al (2013) & & $\begin{array}{l}\text { National Development Plan } \\
\text { (p98) }\end{array}$ \\
\hline Mkhabela (2013) & & Food insecurity (p101) \\
\hline Hendriks (2014) & Food security & \\
\hline Browne et al (2014) & Food security & \\
\hline Baiyegunhi (2014) & Rural household poverty & \\
\hline Adong (2014) & & Smallholder farmers (p108) \\
\hline Lokosang et al (2014) & Food insecurity & \\
\hline Hendriks (2013) & $\begin{array}{l}\text { National Development } \\
\text { Plan and New Growth } \\
\text { Path }\end{array}$ & \\
\hline Bahta et al (2014) & $\begin{array}{l}\text { Role of agriculture in } \\
\text { welfare distribution \& } \\
\text { economic development }\end{array}$ & \\
\hline Matchaya et al (2013) & $\begin{array}{l}\text { Smallholder farmers } \\
\text { association }\end{array}$ & \\
\hline Motsholapheko et al (2012) & $\begin{array}{l}\text { Rural livelihood } \\
\text { diversification }\end{array}$ & \\
\hline Haankuku \& Kirsten (2012) & & $\begin{array}{l}\text { Fifth National Development } \\
\text { Plan (p.66) }\end{array}$ \\
\hline Mbatha \& Antrobus (2012) & $\begin{array}{l}\text { Land redistribution } \\
\text { process }\end{array}$ & \\
\hline Zikhali \& Chilonda (2012) & Fast track land reform & \\
\hline
\end{tabular}

${ }^{*} N D P$ in Zambia

Source: Agrekon (2012, 2013, 2014 \& 2015 randomly selected volumes)

On the other hand, Agrekon is publishing a fair number of articles addressing developmental keywords. For the four years under review, most of the developmental themes related to food security and land reform. The issues of smallholder or smallscale farming also feature prominently while the role of agriculture in economic development features somewhat. This pattern tends to give hope that the economic development question is coming to the fore in the agenda of Agricultural Economics research. We can only hope that it will continue and even be sharpened more. 
Even if I spared the perspectives of the presidential addresses for some or other reason, it can be concluded that to some limited extent, which is growing, AEASA enables agricultural economists to reflect or to link their work with the priorities of the Developmental State. There is, however, ample opportunity and justification for us to do more in this regard going forward.

\section{In Search of a Prosperous farmer - The Friend of the Farmer Economist}

As a member of the agricultural economics collective, who is somewhat letting the Developmental State down, I sometimes feel more liable as an individual. Put differently, I wish I had done more and not abandoned some of the earlier initiatives.

Let me share my work over time. It reflected the shifting emphasis in its quest for perfection and precision, in the process losing traction on addressing developmental imperatives. However, I think I am not alone because, according to Van Rooyen (2000), Tomlinson traversed many hats as an Agricultural Economist, Development Economist and Political Economist! Potgieter (2014) describes it as a ubiquitous trait possessed by agricultural economists.

\subsection{Evaluation of agricultural development projects}

My earliest work was more focused on evaluating agricultural projects. My final year research project at the University of Limpopo was on the topic "Investigation into financial viability of a proposed agricultural development project: With special reference to farmers and contractors, Thabina Valley, Lebowa". This was part of a bigger Thabina Valley project. Then, I learnt how to think ahead and broadly. During the period, I also did several vacation training projects looking at the effects of a Sisal project (in Chloe, Seshego) on labour, the role of cooperative in maize and food production (in Ndebele Cooperative in Nebo), and then in the Salem Citrus Project in Mokerong or Mogalakwena. These were government-driven projects. Even though I do not know where the reports eventually ended, mine was a lot of experiential learning. I also realised even then that there would be a need to redesign some of these projects.

One milestone was also a research report done for both official and academic purposes, focusing on how to settle farmers on agricultural development projects. The report used cash flow projections based on project evaluation approaches. Table 7 summarises the results.

As indicated, the modelling gave a range of alternatives depending on the type of the farmer needed. My own inclination is that we needed a more successful farmer. If it meant creating fewer successful farmers, then let it be. The underlying view, which I still hold, is that a successful farmer tends to benefit many aspects of the economy. 
When we aggregate the benefits accruing from the successful farmers, then we can start experiencing the developmental impact.

Table 7: Models for farmer settlement on agricultural development projects

\begin{tabular}{|l|l|l|}
\hline Farmer Scenario Type & Description & $\begin{array}{l}\text { Number } \\
\text { Settled }\end{array}$ \\
\hline Commercial Risk Taker & No support; Farmer responsible for all cost & 0 \\
\hline Limited Support Farmer & $\begin{array}{l}\text { Fixed (subsidised) wages; Farmer responsible } \\
\text { for other costs }\end{array}$ & 0 \\
\hline Free Farmer & $\begin{array}{l}\text { No govt involvement; market wages + family } \\
\text { labour (fewer farmers) }\end{array}$ & 1 \\
\hline $\begin{array}{l}\text { Free \& Supported } \\
\text { Farmer }\end{array}$ & $\begin{array}{l}\text { Market prices + family; subsidies; (more farmers } \\
\text { settled) }\end{array}$ & 6 \\
\hline Free \& Efficient Farmer & $\begin{array}{l}\text { Market wages, productive workers; Seeks better } \\
\text { prices }\end{array}$ & 12 \\
\hline $\begin{array}{l}\text { Free, Efficient \& } \\
\text { Supported Farmer }\end{array}$ & $\begin{array}{l}\text { Market wages; productive workers; better } \\
\text { market arrangements; Govt. \& Service Centre } \\
\text { Support }\end{array}$ & 11 \\
\hline
\end{tabular}

Adapted from Makhura (1990)

\subsection{Farm management for developing farmers}

My next work involved working with farmers directly to assist them manage their farms as businesses. I published a column in the Small Business News published by the University of Limpopo. The belief was that advocacy messages for the farmer would be heard by many people or authorities through the publication in the business and economic spheres.

The focus was on four areas:

- General farm business management;

- Financing a farm business;

- Marketing farm products; and

- The farm as an organisation (requiring leadership).

\subsection{Conceptualising commercialisation of small-scale farmers}

Later on, I shifted to creating connections between viable farm businesses and overall developmental impact of farmers. That was done through developing 
frameworks and models for commercialisation behaviour. This is the work that made me understand why my dad, as a farmer, behaved the way he behaved with his cattle and time. He left Gauteng and decided to provide services of thatch roofing in the community. That gave him an opportunity to develop, increase and "hold on" to his precious livestock.

My review showed that the commercialisation process goes in stages and there are drivers behind this behaviour (see Table 8).

Table 8: Concepts of commercialisation of subsistence farmers

\begin{tabular}{|l|l|l|}
\hline Concept & Attributes & Policy Implications \\
\hline $\begin{array}{l}\text { Commercialise Surplus } \\
\text { (Fisk) }\end{array}$ & $\begin{array}{l}\text { Consume what is } \\
\text { produced }\end{array}$ & $\begin{array}{l}\text { Self-sufficiency: Subsistence } \\
\text { farmer support (Illima/ } \\
\text { Letsema) }\end{array}$ \\
\hline $\begin{array}{l}\text { Maximise opportunities } \\
\text { (Nakajima; Louw) }\end{array}$ & $\begin{array}{l}\text { Production linked with } \\
\text { markets }\end{array}$ & Develop markets \\
\hline $\begin{array}{l}\text { Risk in Commercialisation } \\
\text { (Von Bron) }\end{array}$ & $\begin{array}{l}\text { Production and market } \\
\text { risks }\end{array}$ & Risk support and mitigation \\
\hline $\begin{array}{l}\text { Commercialise to Access } \\
\text { other goods \& Services } \\
\text { (Makhura, 1994) }\end{array}$ & $\begin{array}{l}\text { Farmers integrated to } \\
\text { other economic activities }\end{array}$ & $\begin{array}{l}\text { Make farmers part of rural } \\
\text { economies }\end{array}$ \\
\hline
\end{tabular}

Adapted from Makhura (1994)

\subsection{Transaction costs and institutional barriers}

The work on commercialisation led me to trace what stops farmers from doing what they are "supposed" to do. Somehow, Transaction Cost Theory or New Institutional Economics came at the right time to guide me understand the issues clearer. With Kirsten and Delgado, we sought to clarify hidden costs in commercialisation.

I ended up joining institutions that I thought were critical to enable farmers to be more effective. Starting at the Development Bank of Southern Africa and later landing at the Land Bank, the quest was to provide solutions for these institutions to better assist farmers and contribute to development. At the Land Bank the issue was how we can use access to finance to make agriculture have developmental impact. This agenda resonates very well with me.

\subsection{Making the the work of Agricultural Economists accessible: Communicating the message}

The other major area that agricultural economists have to traverse is communicating about what their work means to the public. The partnership with the Farmer's Weekly 
publication through "The echoes of the great teacher" column was very satisfying. During the three-year period, I had to prepare messages for the weekly publication. This was an offshoot of the Outlook column that Johan Kirsten started with the Farmer's Weekly. Later, we conceptualised the "Friend of the Farmer" column with the Farming SA publication. Lastly, the "Prosperous Farmer" with The NuFarmer Newsletter did not go very far. These were meant to relay the conceptualisation of the theory of farming and to relate it to the daily experiences of the farmer so as to enable the utility of theory. One of the useful theoretical frameworks was the "New old theory of commercialisation for prosperity" based on Maslow's Hierarchy of Needs, which articulates the various basic needs up to the advance need of selfactualisation. This is similar to Chaminuka (2012), who argued, based on Maslow's Hierarchy of Needs, that international priorities about conservation cannot be realised well in Africa until such a time when people's basic needs have been met, as conservation is likely to be considered a secondary need.

The Commercialisation for Prosperity approach argues that farmers will commercialise initially to meet basic needs and will pursue such needs until they reach the highest level of self-actualisation that epitomises prosperity in a sequential way. As such, it asserts that:

- Farmers farm for prosperity;

- Agriculture performance needs to be on par with other sectors;

- Rural industries should provide investment opportunities;

- There is a need for policies and institutions to consolidate (ring fence) prospects and opportunities in commercialisation;

- The developmental aspect is that prosperity is for farmers themselves and for others.

\subsection{The rural economist}

Since encountering the work of Robert Chambers in the 1980s, the question of rural development had preoccupied my mind. In the mid-2000s, I had an opportunity to reflect on how to understand the rural economies within the hectic developmental agenda of service delivery of the developmental state. Together with the DBSA and the University of Limpopo, we sought to interrogate the concept of rural development in the then prevailing contemporary context. Through the medium of the South African Rural Development Quarterly (SARDQ), two views emerged. From the DBSA, we argued that rural development will only be viable when looked at beyond agriculture (Makhura, 2004a; 2004b; 2004c). The view was met with a very vociferous school of thought from the University of Limpopo, which argued that agriculture is central to rural development (Belete, Moholwa and Chaminuka, 
2004). The Limpopo perspective was in line with the University of Pretoria that particularly asserted that a strong commercial agriculture is a prerequisite for the development of rural areas. However, this exciting engagement gave birth to the story of ruralisation, which focuses on supporting rural lifestyle!

\section{Finding the Nexus for the Developmental Developmental Agricultural Economist}

The nexus of the agricultural economist and the Developmental State is at creating a viable farming system that will make agriculture contribute significantly to employment, food security, poverty alleviation, reduction of inequalities and economic growth. This nexus is what will make the value or significance of agriculture prominent. The question is: what would be required to make the Agricultural Economist more developmental? How different is a Development(al) Agricultural Economist (DAE) from a Development Economist?

\subsection{Towards a new developmental agricultural economist (DAE)}

A development(al) agricultural economist (DAE) has to ensure that the outputs, outcomes or financial surpluses of the viable farm impact on more people (and not just on an individual farmer). ADAE has to understand and comprehend or appreciate what makes "a viable farm enterprise or unit", as well as the associated policy instruments and outcomes. Of critical importance is to be able to link quantitatively or qualitatively the formal relations between "viable farms" and the policy outcomes.

The other area of nexus is in conglomerating (or aggregating) viable farms into a mega farm that benefits more beneficiaries. In a traditional sense, this is a variant to agricultural development projects, which used to focus on "viability of an overall project" where the participants only share the spoils with stronger participants such as management services, suppliers and service providers and buyers benefitting economically, while the actual farmers are turned into "executive labourers" who make an economic loss (Makhura, 2008b). The DAE has to connect and comprehend the contemporary policy intentions of the Developmental State and the state of agriculture. This is the group that could tell us more about the contribution and implications for agriculture sector and the farmer in the NDP, AgriBEE, ASGISA, GEAR, the Constitution, the RDP, and even how the farmer is affected by the Freedom Charter. At the end, what will all these mean to the viability of the farmer and overall impact on the agriculture sector? Figure 2 illustrates that the DAE will have to do policy analysis and advisory services. 


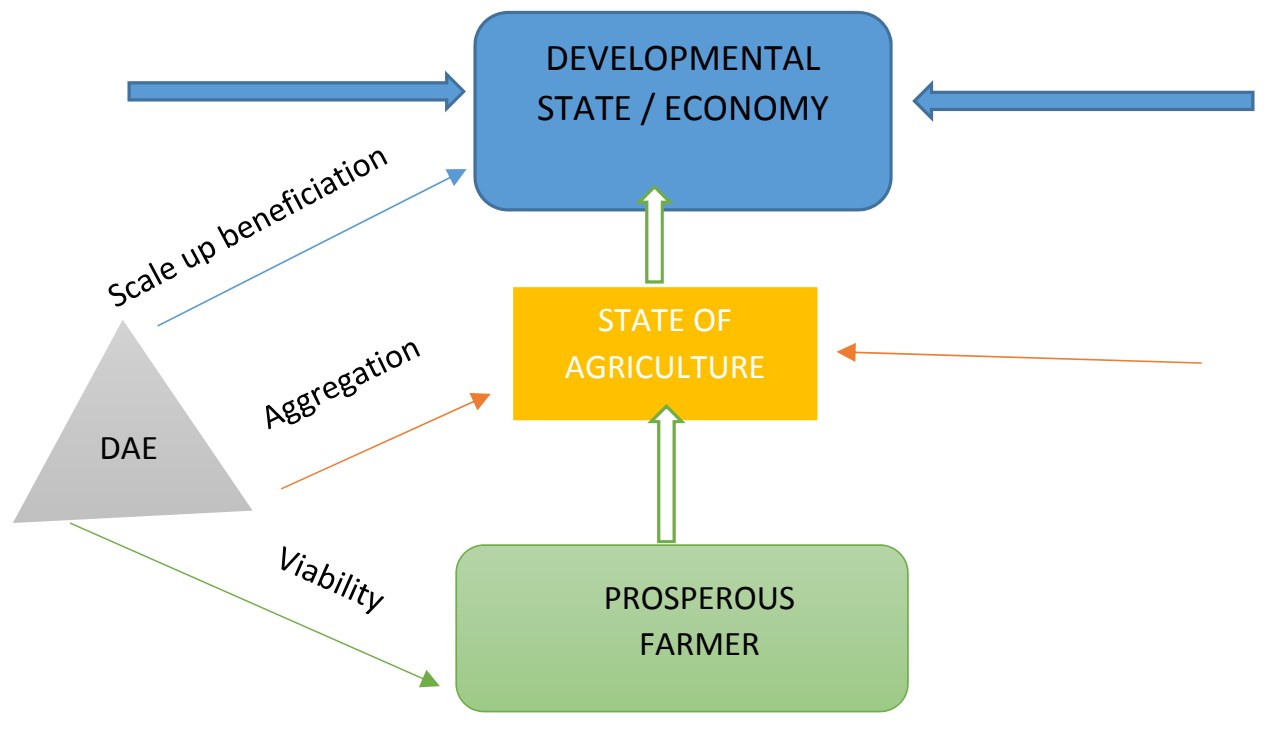

Figure 2: The role of DAE in a Developmental State

\subsection{Friendship with the farmer}

The other nexus is at the "Friendship with the farmer" level. While farmers perform a very difficult task producing and providing food under trying circumstances, they are normally left to their own devices. When farm gate prices are high making farming viable, farmers are accused of making food inaccessible to the poor. However, when farm gate prices are low, farmers are expected to be efficient. Farmers need a friend. Some of us have signed up for the call of "Friendship with the Farmer". There may be a need for a network of "Friends of the Farmer" (FOFN), which should extend to the diverse array of farmers (commercial, emerging, small scale, etc.) that we have in South Africa. However, new developmental agricultural economists will need to empathise with the farmer.

There is therefore a need for Friendship Economics or a "Friend of the farmer" Economics. This field would apply the value and potential contribution of emotions in enhancing the productivity and performance of farmers. It would seek to determine the need and provisioning of emotional-type support services to farmers. The major assumption is that farmer is an emotional entity. The developmental momentum is then about scaling out or enlarging the beneficiation to a larger scale or scope. Hence, the FoFN would encourage "One Farmer - One Friend" and "One Farmer - One Agricultural Economist". The mission is to make sure that we have as many viable farmers as possible and most importantly, that they are made aware of national 
or state priorities or expectations on the farmer or agricultural sector. This DAE has to intercede on behalf of the farmer with the state and other stakeholders. In line with Oosthuizen (2008), who committed to working on economics education, the "Friend of the Farmer" Network is something I would like to work on in my next 25 years. So, if I'm not seen at an AEASA event, I would be busy befriending the farmer!

\subsection{Economics of family farming}

The next nexus is around "Family Farming". This is where Developmental Agricultural Economics starts. A DAE should appreciate and even connect with the two concepts of "Family Economics" and "Farming Economics". These two make the Economics of Family Farming. The DAE has to usher families to the state or connect families with the state's priorities in agriculture. When all family economies are optimal, it is then that we could talk about a state of development. It is important to caution on what Family Farming is not. It is not about community gardens with meagre individual allotments that become a waste of people's time. My observation over the past 25 years has been that the average lifespan of such initiatives is just two years after which people start leaving and attend to more important things. It is also not a club of family members and does not operate like a fundraising project.

Family Farming is about creating sustainable livelihoods to enable families to provide food, create jobs and to access other goods and services through a family institution. It relieves the pressure from state dependency. Put differently, the first point of a viable farm's development impact is at a family or household level. Then it can impact at community level, local level, provincial level and national level. That kind of progression should be observed closely and impact measures determined at different levels (see Table 9).

Table 9: Stepping up farm impact

\begin{tabular}{|l|l|}
\hline Level & Developmental impact areas \\
\hline Family & Livelihood; ability to access other goods and services \\
\hline Community & Provision of food and employment \\
\hline Municipalities & Farm linkage with non-farm \\
\hline Provincial & Regional food distribution \\
\hline National & Jobs, equality and national food security \\
\hline International & Food trade \\
\hline Universal & Human life \\
\hline
\end{tabular}




\subsection{The spirit of farming and the farming spirit}

The spirit of farming and the farming spirit is about the universal contribution of farming. Three dimensions that are noteworthy with regard to this are:

- That life, as illustrated in the Bible, centres around farming, considering the various parables from Jesus about farming.

- Spiritually based socio-economic movements such as "Farming 4 Jesus".

- Spirituality being propagated as a value in developmental farming such as the notion of "Valuing Spirituality in Development" (Bahá'i International Community, 1998).

\section{Conclusions}

The Developmental State or Developmental Economy is likely to entrench further in South Africa as the gap between delivery and expectations from the state increases. New international priorities in the Sustainable Development Goals (SDGs) also align with Developmental State thinking. Many instruments will be tried or implemented to give effect to the goals of the Developmental State. Although agriculture does respond to the patterns of the Developmental State, it will need special players in the sector to assist farmers to make agriculture play a meaningful role in the developmental economy.

Measuring such a contribution of agriculture will have to go beyond the conventional approach and will have to consider other alternatives. Agriculture does contribute significantly to the developmental economy, but its contribution could be made more prominent and visible. Agricultural economists are best suited to clarify such a contribution and, more so, could guide the sector to channel resources accordingly.

There is therefore a need to revisit how agricultural economists are trained and developed in their careers. The lecture has suggested some areas for consideration to make agricultural economists more developmental. Understanding the basic viability of the farm, as well as aggregation (or conglomeration) of many viable farms and scaling up such aggregated performance to benefit other areas of the economy will make agriculture a significant instrument in the Developmental State. When such a condition is clear, motivating for more agricultural budget allocation will be easier.

Basically, the nexus for the Developmental Agricultural Economist is about ensuring a viable farm, creating friendship with the farmer, optimising the family farming, valuing the spirit of farming, and considering a special approach to evaluating agricultural projects, programmes and policies emerging from the Developmental State. 
If we were to support the mission of the Developmental State, Professor Tomlinson would judge us more leniently.

Finally, let me take the opportunity to address our fellow young, aspiring and emerging agricultural economists. In his book, The spirit of leadership, Dr Myles Munroe states in that "How you define yourself is the single most important statement you can make about yourself, and it is the heart of attitude. The spirit of leadership will emerge from your self-definition." As agricultural economists, we need to define ourselves as a collective and as individuals.

Personally, I have learnt that:

- Once you start a mission stick to it as time is the highest judge of deeds. If you decide to be a DAE, please stick to it.

- Do things with passion, conviction and a sense of service as that exudes the positive energy everyone needs. The course of farming is not equal to any mission in life because everyone needs to eat first and then do other things. As such, find your niche and stick to it! Do it for yourself, but the greatest value is in doing it for others.

\section{References}

Adong, A. 2014. Impact of household, membership of farmer groups on the adoption of agricultural technologies in Uganda: Evidence from Uganda Census of Agriculture 2008/09. Agrekon 53(2):108-136.

AEASA. 2011. Fifty years of achievement. The Agricultural Economics Association of South Africa. Pretoria.

Bahá'í International Community. 1998. Valuing spirituality in development. Initial considerations regarding the creation of spiritually based indicators for development. London: Bahai Publishing Trust.

Baiyegunhi, L.J. 2014. Social capital effects on rural household poverty in Msinga, KwaZuluNatal, South Africa. Agrekon 53(2): 47-64.

Bahta, Y.T., Willemse, B.J. and Grové, B. 2014. The role of agriculture in welfare, income distribution and economic development of the Free State Province of South Africa: A CGE approach. Agrekon 53(1): 46-74.

Browne, M., Ortmann, G.F. and Hendriks, S.L. 2014. Household food security monitoring and evaluation using a resilience indicator: An application of categorical principal component analysis and simple sum of assets in five African countries. Agrekon 53(2): 25-46.

Belete, A., Moholwa, B. and Chaminuka, P. 2004. Comments on rural definition. SARDQ 2(2): $21-22$.

Chaminuka, P. 2012. Evaluating land use options at the wildlife/livestock interface: An integrated spatial land use analysis. PhD thesis, Wageningen University, Netherlands. 
Chauke, P.K. 2013. Application of Cooperative principles in the governance of land reform projects. A research proposal.

Coetzee, J.K. 1987. Introduction. In Coetzee, J.K. (ed.), Development is for people, 1-14. Johannesburg: Southern Book Publishers.

Dlamini, T.S.,Verschoor, A.J. and Fraser, G.C.G. 2013. Exploring options in reforming South African land ownership: Opportunities for sharing land, labour and expertise. Agrekon 52(Supplement 1): 24-45.

Edigheji, O. 2010. Introduction. In Constructing a democratic developmental state in South Africa: Potentials and challenges. Cape Town: HSRC Press.

Education Training Unit. 2015. What is developmental state? Available at http://www.etu.org.za/ toolbox/docs/govern/state.html (Accessed 29 November 2015).

Fraser, G. 2010. How the leopard has changed its spots: Past dynamics and future opportunities? Agrekon 49(1): 1-16.

Haankuku, C. and Kirsten, J. 2012. Improving agricultural competitiveness by setting priorities for investments in crop research: A case of sugarcane farmland transfers. Agrekon 51(4): 63-80.

Hendriks, S. 2013. South Africa's National Development Plan and New Growth Path: reflections on policy contradictions and implications for food security. Agrekon 52(3): 1-17.

Hendriks, S. 2014. Food security in South Africa: Status quo and policy imperatives. Agrekon 53(2): 1-24.

Johnson, C. 1982. MITI and the Japanese miracle: The growth of industrial policy, 1925-1975. Stanford: Stanfort University Press.

Johnston, BF. 1992. Agriculture and structural change: Are there historical lessons for South Africa. Simon Brand Memorial Address. Agrekon 31(4): 149-156.

Jordaan, H., Grové, B. and Matthews, N. 2013. Investigating potential financial gains from using production inputs more efficiently. Agrekon 52(Supplement 1): 87-100.

Land Bank. 2010. Policy INSIGHT. Quarter 3 (Jul-Sep) 2010. Agricultural Economic Research and Innovation Services.

Lokosang, L.B., Ramroop, S. and Zewotir. 2014. Indexing household resilience to food insecurity shocks: The case of South Sudan. Agrekon 53(2): 108-136.

Makhura, M.T. 1990. Model for farmer settlement on agricultural development projects: A case of Champagne Citrus Project. Unpublished Bachelor of Commerce (Honours) Research Report, University of South Africa.

Makhura, M.N. 2008. Positioning agriculture within the changing environment. Keynote Address at the Stakeholder Consultative Workshop on Mpumalanga Sector Plan, Middleburg, 28-30 April 2008.

Makhura, M.N. 2004a. Rural viewpoint: Rural definition revisited. South Africa Rural Development Quarterly (SARDQ) 2(1): 9-10.

Makhura, M.N. 2004b. Rethinking rural (view): Where are rural areas in South Africa? South Africa Rural Development Quarterly (SARDQ) 2(2): 19-20.

Makhura, M.N. 2004c. Rethinking rural: Do rural institutions matter? South Africa Rural Development Quarterly (SARDQ) 2(4): 16-19. 
Makhura M.N. 2008a. Agricultural Policy and Development. Presented at the 60th Anniversary of the UKZN Agriculture. Pietermaritzburg. 1 December 2008

Makhura, M.N. 2008b. Rethinking agricultural development finance in South Africa: Options for implementation. Agrekon 47(1): 1-18.

Marwala, T. 2006. Foundations for a developmental state: A case for technical education. Available at http://arxiv.org/ftp/arxiv/papers/0907/0907.2019.pdf (Accessed 28 November 2015).

Maserumule, M.H. 2010. Consolidating a developmental state agenda: A governance challenge. Chapter 2. In Kondlo, K. and Maserumule, M.H. (eds). The Zuma Administration: Critical Challenges. HSRC Press: Cape Town.

Maseti, Z. 2015. Personal communication.

Matchaya, G.C. and Perotin. 2013. The impact of cooperative patronage: The case of National Small Holder Farmers'Association (NASFAM) of Malawi in Kasungu District. Agrekon 52(2): 75-103.

Mbatha, N.C. and Antrobus, G.G. 2012. A cooperative benefit framework in South Africa's land redistribution process: A case of sugarcane farmland transfers. Agrekon 51(4): 81-104.

Mkandawire, T. 2001. Thinking about developmental states in Africa. Cambridge Journal of Economics 25(3). Available at http://ss.rrojasdatabank.info/Mkandawireafrica.pdf(Accessed 6 December 2015).

Mkhabela, T. 2013. Exploring pricing policy options to stimulate healthy eating in South Africa: Seeking consensus using the Delphi technique approach. Agrekon 52(Supplement 1): 101117.

Mmbando, F.E., Wale, E.Z. and Baiyegunhi, L.J.S. 2015. Determinants of smallholder farmers' participation in maize and pigeonpea markets in Tanzania. Agrekon 54(1): 96-119.

Motshalapheko, M.R., Kgathi, D.L. and Vanderpost. 2012. Rural livelihood diversification: A household adaptive strategy against flood variability in the Okavango Delta, Botswana. Agrekon 51(4): 41-62.

Oosthuizen, L.K. 2008. Economics education: Aspirations and responsibilities of the profession. FR Tomlinson Commemorative Lecture. Agrekon 47(2): 165-179.

Potgieter, J.T. 2014. The F.R. Tomlinson memorial lecture: The ubiquitous

agricultural economist Bloemfontein, 16 February 2012, Agrekon, 53:3, 116-128, DOI:

10.1080/03031853.2014.931704

Thom, A. and Conradie, B. 2013. Urban agriculture's enterprise potential: Exploring vegetable box scheme in Cape Town. Agrekon 52(Supplement 1): 64-86.

Timmer, C.P. 1990. The agricultural transformation. In Eicher, C.K. and Staat, J.M. (eds.), Agricultural development in the third world, 47-69. Baltimore and London: The John Hopkins University Press.

Van Rooyen, C.J. 2000. The dilemma of a contemporary agricultural economist: Will the real Professor Tomlinson please step forward! FR Tomlinson Memorial Lecture. Agrekon 39(3): 223-234.

Van Zyl, J. 2008. On agricultural economics and the economics of agriculture - perspective from a distance. FR Tomlinson Commemorative Lecture, 21 July 2008, University of Pretoria. Agrekon 47(4): 395-409. 
Vink, N. 2001. Small farmer research in South Africa: A survey. FR Tomlinson Memorial Lecture delivered 1 June 2001 at Laborie, Paarl. Agrekon 40(2): 130-186.

Van Rooyen, J. and Vink, N. 2015. The role of agricultural economists in the Development Bank of Southern Africa. In Makhura, M.N., Troskie, D., Ngqangweni, S., Van Wyk, B. and Chauke, P.K. (eds.), AEASA in Practicia - The role of practicing agricultural economists in South Africa. Published by Agricultural Economics Association of South Africa. Pretoria. ISBN: 978-0-9922409-5-0

Zikhali, P. and Chilonda, P. 2012. Explaining productivity differences between beneficiaries of Zimbabwe's Fast Track Land Reform Programme and communal farmers. Agrekon 51(4): 144-166. 